\title{
Attitude, Duties and Responsibilities: The Hallmark of Self-Regulators in Business Practicum Program
}

\author{
Amelie L. Chico, DM, FRIM; Vicente Salvador E. Montaño, DBA \\ College of Business Administration Education, University of Mindanao, Philippines
}

\begin{abstract}
Present research in self-regulated learning focused on contextualized task, which allow students to generalized learning. However, few researches delve on the role of the practicum program and the host-training establishment in measuring selfregulated learning among graduating business students. The study investigates the significant presence of self-regulated learners among practicum students through the significant relationship between grade point average and the supervisor rated practicum performance. All the 135 business practicum students from the College of Business Administration for the academic year 2014-2015 participated in the study. The academic performance of the students, from their first year to fourth year demonstrate that the different practicum criteria; duties, quality, punctuality, attitude and grooming correlates with the different year level. The ward hierarchal cluster analysis segments the practicum students between self-regulators and non-selfregulators. Later the variance of analysis confirmed the significant differences across all practicum performance criteria. In addition, the discriminant analysis method shows that that attitude (0.74) and duty (0.503) were helpful in predicting group membership between self-regulating and non-self-regulating students.
\end{abstract}

Keywords: self-regulated learning, business practicum and discriminant analysis

\section{INTRODUCTION}

$\mathrm{T}$ he changing nature of business and industry calls for changes to the educational process that should drive business education advancement. The business education program needs to prepare students in the different scenarios they shall encounter in the real world (Clinebell \& Clinebell, 2008). To some extent, Self-Regulated Learning (SRL) helps students to conceptualize cohesive business fundamentals that lead to develop acceptable business strategy and decision (Pintrich \& Zusho, 2007). Over the past few years the selfregulated learning is part of the business education which aim to help practicum students learn practical business concepts, understand the myriad of situations that lead to a better practice of business administration (Kuiper, Murdock, \& Grant).

Self-regulated learning happens when the student doing the learning has a major responsibility (Nicol \& Macfarlaneâ€• Dick, 2006) for planning (McLoughlin \& Lee), practicing (Young, 2005), evaluation (Sungur \& Tekkaya, 2006) of their learning experience. Experts claimed that self-regulated learning is the way to learn best (Schunk, 2005). However, in the tertiary education, students were conditioned to learn didactically, a passive learning format
(Banyard, Underwood, \& Twiner, 2006). Nevertheless, the practicum program, a metacognitive learning, requires students to process and use information from learning experience daily compared to the didactic classroom setup (Perry, Hutchinson, \& Thauberger, 2008).

In retrospect, self-regulated learning in the practicum program is not haphazardly conducted and not "learning by your-self" scheme (Perry, Hutchinson, \& Thauberger, 2007). Rather, the practicum coordinator and assigned supervisor assist the student in their information gathering and decisionmaking. The practicum program has an established purposeful endeavor, an organized framework in the context of a learning framework. The learning acquired during practicum is planned and students recognize learning as it happens (Loyens, Magda, \& Rikers, 2008).

\section{FRAMEWORK}

This study is based on the context of Educational Psychology of Self-Regulated Learning (SRL) theory, which has become the recent focus of educational practice. The study of (Zimmerman \& Schunk, 1989), (Zimmerman, 1989), (Zimmerman, 1990) identified the distinctive features of the student's capability to acquire knowledge and skills through self-regulated learning. Zimmerman work on the realities of student's academic development. Students are expected to take greater learning responsibilities as they progress in college. It was demonstrated in their research that success in academic occur when teachers and students engages in metacognitive learning which entails planning, evaluation and adjustment of thoughts (Azevedo \& Hadwin, 2005). SelfRegulated Learning (SRL) theory details this metacognitive process. In the span of several years, SRL researches focused on advances of cognitive science, which proceed to claim that student engaged in their learning process take greater responsibility for their learning and their academic performance improves (Alexander, 2008), (Azevedo, 2009). The SRL model used the three phases of the feedback cycle: planning, practice and evaluation (Nicol \& Macfarlaneâ€• Dick, 2006).

In each phase of self-regulated learning feedbacks to learners, improve their work performance. Expected among learners in the planning are to accurately assess their academic situation and react correspondingly by choosing a strategy that can overcome their specific academic challenge. At this phase, achievable short and long-term objectives are clearly set (Azevedo, 2005). It is at practice phase, when learners 
implement their selected strategies and calibrate plan as they self-monitor their progress. The last phase, evaluation, learners evaluate the effectiveness of their strategy in helping them achieve their goals (Zimmerman \& Kitsantas, 2005). Gathering feedbacks from the evaluation is the next learning phase (Nicol \& Macfarlaneâ€• Dick, 2006).

\section{OBJECTIVES OF THE STUDY}

The study aims to determine the different status of self-regulated learning among practicum students through the three phases of feedback cycle: planning, practice and evaluation. In the process, the study determines the presence of a significant cluster of self-regulated learners and the quality performance variable that significantly distinguish the different cluster of self-regulated learners. In the end, the study identified the present learning phase and recommend steps for the next learning to design a practicum program that produce business graduates with industry-based competency.

\section{METHOD}

The study used the universal sampling method; all 135 practicum students from the period of the first semester of school year 2014-2015 from the College of Business Administration education participated in the study. In order to determine which variable significantly distinguish clusters of self-regulated learners, the study used the academic performance of students through the semester grade point average (GPA) from their first year to fourth year. In addition, the study used the Individual Practicum Evaluation from Academic Planning and Services. The direct supervisor of the practicum students directly filled up the form based on their assessment on the quality work performance of the students dived into two areas: duties, responsibilities, and quality performance. Furthermore, quality performance is divided into the following: quality of work, punctuality and attendance, attitude towards the supervisor and personal grooming. The filled up evaluation form is enclosed in a signed sealed envelope and directly sent to the practicum coordinator. Both the academic performance and individual practicum evaluation are converted into percentage rating.

This study portrays the SRL as an event, which demonstrate localized phenomena in the practicum program of the college, with a beginning and end in time (Winne). The measure of the SRL as an event is through the supervisor observation of the practicum student. Measuring SRL is by questionnaires administered to the supervisor, which is a recorded trace methodology observational measure of the practicum students (Matthews, Ponitz, \& Morrison, 2009). Supervisors were asked to evaluate the observable indicator such as the quality of work, punctuality and attendance, attitude towards supervisor and personal grooming. Trace method are often used in older students expected to have meta-cognitive abilities necessary to demonstrate their SRL process (Kaplan, Lichtinger, \& Margulis). In terms of the specific instrument, numerous related literatures reveal that there was no single-report questionnaire frequently used over another. This conveys that researchers are still struggling to define sufficiently SRL (Lennon).

Self-regulated learning (SRL) is either an aptitude or an event (Moos \& Azevedo, 2008). The questionnaire can measure SRL aptitude, which varies among students across time, over task and settings. Other studies raises doubt to categorize SRL as an aptitude or a trait (Malmberg, JÃărvenoja, \& JÃărvel Ãa).

The study used the ward hierarchal cluster analysis to segment the practicum students that relate to their present phases of feedback whether they are in the cluster of planning, practice or evaluation. Central to this method is the notion of degree of similarity in the phase of practicum students' selfregulated learning. This method subdivided the cluster of practicum students into agglomerative methods, separating students into finer groupings. The technique form the subdivided partition in a technique that minimizes loss associated with each grouping that is readily interpretable in terms of error-sum-of square criterion, ESS (Vollmeyer \& Rheinberg, 2006).

In trying to identify which among the scope of work significantly distinguish the different self-regulated learners among practicum students, the study used the discriminate function analysis. This method determines which among the scope of work discriminate between students in planning, practice or evaluation phase (Barnard-Brak, Paton, \& Lan).

The Grade Point Average (GPA), which demonstrates the academic performance of students at end of semester are part of the students' official academic record, which reflect in the transcript of record (TOR). To interpret the academic performance of students, the study used the undergraduate grading scales from the University of Victoria British Columbia.

\begin{tabular}{|c|c|c|}
\hline Rating & Description & Interpretation \\
\hline $\begin{array}{l}80 \& \\
\text { below }\end{array}$ & Acceptable & $\begin{array}{l}\text { This is earned by work that indicates an } \\
\text { adequate comprehension of the course } \\
\text { material and the skills needed to work with } \\
\text { the course material and that indicates the } \\
\text { student has met the basic requirements for } \\
\text { completing assigned work and/or } \\
\text { participating in class activities. }\end{array}$ \\
\hline 81 to 85 & Good & $\begin{array}{l}\text { This is earned by work that indicates a good } \\
\text { comprehension of the course material, a good } \\
\text { command of the skills needed to work with } \\
\text { the course material, and the student's full } \\
\text { engagement with the course requirements and } \\
\text { activities. Normally achieved by the largest } \\
\text { number of students. }\end{array}$ \\
\hline 86 to 90 & Very Good & $\begin{array}{l}\text { This represents a more complex } \\
\text { understanding and/or application of the } \\
\text { course material. }\end{array}$ \\
\hline 91 to 95 & Excellent & $\begin{array}{l}\text { This is earned by work which is technically } \\
\text { superior, shows mastery of the subject matter }\end{array}$ \\
\hline 96 to 100 & Outstanding & $\begin{array}{l}\text { This offers original insight and/or goes } \\
\text { beyond course expectations. Normally } \\
\text { achieved by a minority of students. }\end{array}$ \\
\hline
\end{tabular}




\section{STATISTICAL TREATMENT OF DATA}

The academic performance of the majority of students from first year to third year is within the ranges of 81 to 85 , which is good. This academic performance is earned by work that indicates a good comprehension of the course material, a good command of the skills needed to work with the course material, and the student's full engagement with the course requirements and activities. Meanwhile, academic achievements significantly improve during fourth year. Most students in their senior year have a GPA that is within the range of 86-90, which is very good. This represents a more complex understanding and/or application of the course material.

\section{First year}

Most first year students, 80 or 59 percent in their first semester, 90 or 67 percent in their second semester, academically performed well with GPA of 81 to 85 . This indicate a good comprehension of the course material, a good command of the skills needed to work with the course material, and the student's full engagement with the course requirements and activities, normally achieved by the largest number of students. There were 30 or 22 percent and 26 or 19 percent in the first and second semester respectively, have grades 80 and below. This is acceptable which indicates an adequate comprehension of the course material and the skills needed to work with the course material and that indicates the student has met the basic requirements for completing assigned work and/or participating in class activities. Likewise, there were 21 or 16 percent in first semester and 17 or 13 percent in second semester of first year with a very good GPA of 86 to 90 . This is an indication of their ability to process more complex understanding and/or application of the course material. A very few, four or three percent and two or one percent in the first and second semester respectively reached excellent. This academic performance can only be earned by work, which is technically superior, shows mastery of the subject matter.

Second year

Majority of second year students 79 or 59 percent in both the first semester and second semester earned good GPA from 81 to 85 . This is aptly described as a good comprehension of the course material, a good command of the skills needed to work with the course material, and the student's full engagement with the course requirements and activities, normally achieved by the largest number of students. Further, there were 36 or 27 percent of sophomores in the first semester and 32 or 34 percent during their second semester earned a very good GPA, from 86 to 90 . This indicates that their ability for a more complex understanding and/or application of the course material. Meanwhile, there were 20 or 15 percent in their first semester and 18 or 13 percent in their second semester, who got an acceptable level of GPA 80 and below. An indication of an adequate comprehension of the course material and the skills needed to work with the course material and that indicates the student has met the basic requirements for completing assigned work and/or participating in class activities. However, only six or four percent of sophomores in their second semester reached a very good GPA, 86 to 90 , which indicate technically superior, shows mastery of the subject matter.

\section{Third Year}

During their third year most students, 78 or 58 percent in the first and 72 or 53 percent in the second semester realized good GPA, from 81 to 85 rating. This show a good comprehension of the course material, a good command of the skills needed to work with the course material, and the student's full engagement with the course requirements and activities, normally achieved by the largest number of students. Moreover, there were 49 or 36 percent in the first and 40 or 30 percent in the second semester junior students earned very good GPA, 86 to 90, which demonstrate their ability to represents a more complex understanding and/or application of the course material. Conversely, there were only eight or six percent in the first, 13 or 10 percent in the second semester whose GPA is acceptable, 80 and below. This illustrate an adequate comprehension of the course material and the skills needed to work with the course material and that indicates the student has met the basic requirements for completing assigned work and/or participating in class activities.

\section{Fourth year}

During their senior year, business students really demonstrate an improvement in their cognitive level through an increase of their GPA. Unlike in their first year to third year, most senior 99 or 73 percent in the first and 108 or 80 percent earned a very good GPA, 86 to 90 percent which confirm their ability to represents a more complex understanding and/or application of the course material. Meanwhile, there were 16 or 12 percent in the first and 23 or 17 percent in the second semester realized excellent GPA, 91 to 95, illustrating work which is technically superior, shows mastery of the subject matter.

In order to determine if there are significant groupings of practicum students among the fourth year graduating students of first semester 2014-2015, the cluster analysis method was used. This method seeks to classify students as much as differences in their segment in terms of academic performance and the scope of work in terms of duties, punctuality, attitude grooming and quality of work.

Utilizing the hierarchical cluster analysis, Ward's cluster method with squared Euclidean distance under measure there were three significant clusters of practicum students. The first group which are the composed of 15 practicum students, 11 percent, are classified in planning phase, 99 or 73 percent are in practice phase and 21 practicum students or 16 percent of the respondents are in evaluation phase. Furthermore, ANOVA was used in order to verify if they significantly differ in their consumer behavior. 
Table 1. Percentage Distribution of Grades of Business Students

\begin{tabular}{|c|c|c|c|c|c|c|c|c|c|c|c|c|c|c|c|c|}
\hline & \multicolumn{4}{|c|}{ SY 2010-2011 } & \multicolumn{4}{|c|}{ SY $2011-202$} & \multicolumn{4}{|c|}{ SY 2012-2013 } & \multicolumn{4}{|c|}{ SY 2013-2014 } \\
\hline Grades & $1 \mathrm{st}$ & $\begin{array}{l}\mathrm{ar}-1 \mathrm{st} \\
\mathrm{m}\end{array}$ & & $\begin{array}{l}\mathrm{rr}-2^{\text {nd }} \\
\mathrm{n} .\end{array}$ & & $\begin{array}{l}\mathrm{ar}^{\mathrm{a}-1^{\mathrm{st}}} \\
\mathrm{n} .\end{array}$ & & $\begin{array}{l}\text { Ir- } 2^{\text {nd }} \\
\text { n. }\end{array}$ & & $\begin{array}{l}\mathrm{ar}-1^{\mathrm{st}} \\
\mathrm{n} .\end{array}$ & & $\begin{array}{l}\mathrm{Ir}-2^{\text {nd }} \\
\text { n. }\end{array}$ & & $\begin{array}{l}\text { ar- } 1^{\mathrm{st}} \\
\mathrm{n} .\end{array}$ & & $\begin{array}{l}\mathrm{r}-2^{\text {nd }} \\
\text {. }\end{array}$ \\
\hline $80 \&$ below & 30 & $22 \%$ & 26 & $19 \%$ & 20 & $15 \%$ & 18 & $13 \%$ & 8 & $6 \%$ & 13 & $10 \%$ & 1 & $1 \%$ & & \\
\hline 81 to 85 & 80 & $59 \%$ & 90 & $67 \%$ & 79 & $59 \%$ & 79 & $59 \%$ & 78 & $58 \%$ & 72 & $53 \%$ & 17 & $13 \%$ & 4 & $3 \%$ \\
\hline 86 to 90 & 21 & $16 \%$ & 17 & $13 \%$ & 36 & $27 \%$ & 32 & $24 \%$ & 49 & $36 \%$ & 40 & $30 \%$ & 99 & $73 \%$ & 108 & $80 \%$ \\
\hline 91 to 95 & 4 & $3 \%$ & 2 & $1 \%$ & & & 6 & $4 \%$ & & & 10 & $7 \%$ & 16 & $12 \%$ & 23 & $17 \%$ \\
\hline 96 to 100 & & & & & & & & & & & & & 2 & $1 \%$ & & \\
\hline Total & 135 & $\begin{array}{c}100 \\
\%\end{array}$ & 135 & $\begin{array}{c}100 \\
\%\end{array}$ & 135 & $\begin{array}{c}100 \\
\%\end{array}$ & 135 & $\begin{array}{c}100 \\
\%\end{array}$ & 135 & $\begin{array}{c}100 \\
\%\end{array}$ & 135 & $\begin{array}{c}100 \\
\%\end{array}$ & 135 & $\begin{array}{c}100 \\
\%\end{array}$ & 135 & $\begin{array}{c}100 \\
\%\end{array}$ \\
\hline
\end{tabular}

Generally, supervisors of organization rated practicum students excellent $(M=95.12$, S.D.=3.56) in the delivery of their work duties and task assigned to them in the organization. Similarly, the evaluating cluster of practicum students has a rating of excellent $(\mathrm{M}=95.95$, S.D.=2.71) while the second cluster of students has a rating of $\operatorname{good}(\mathrm{M}=$ 88.47, S.D. = 2.42) in their delivery of duties and task. Business practicum students were rated very good $(\mathrm{M}=$ 94.26 , S.D. $=4.05$ ) by their supervisors in the quality of their work. The first cluster of students also earned a very good rating $(\mathrm{M}=94.93$, S.D.= 3.57), while, the second cluster of students earned a good rating $(M=88.93$, S.D.= 3.77) in the quality of their work. Supervisors rated the punctuality of practicum students as very good $(\mathrm{M}=94.93$, S.D. =4.96). Meanwhile, the first cluster of students earned a rating of excellent $(\mathrm{M}=95.83$, S.D. $=4.01)$ and on the other hand, the second cluster of students earned a rating of $\operatorname{good}(\mathrm{M}=87.67$, S.D. =5.94) in their punctuality. Generally, business practicum student has an excellent work attitude $(\mathrm{M}=97.18$, S.D. =3.90), the first cluster of students was also rated excellent $(\mathrm{M}=98.27$, S.D. $=2.04)$ while the second cluster was rated good $(M=88.47$, S.D. $=4.34)$. Lastly, excellent on grooming $(M=97.70$, S.D. $=3.52)$ is the rating of supervisors to practicum students. The first cluster was excellent $(\mathrm{M}=$ 98.28, S.D. =2.69), while the second cluster earned very good $(\mathrm{M}=93.07, \quad$ S.D. $=93.07)$ in grooming.

Table 2. Self-Regulators and Non-self-regulators basic practicum performance comparison

\begin{tabular}{|c|c|c|c|c|c|c|}
\hline & & $\mathrm{N}$ & Mean & Std. Deviation & Minimum & Maximum \\
\hline \multirow[t]{3}{*}{ DUTIES } & Non-self regulators & 15 & 88.47 & 2.42 & 84 & 90 \\
\hline & Self-Regulators & 120 & 95.95 & 2.71 & 90 & 100 \\
\hline & Total & 135 & 95.12 & 3.56 & 84 & 100 \\
\hline \multirow[t]{3}{*}{ QUALITY } & Non-self regulators & 15 & 88.93 & 3.77 & 80 & 94 \\
\hline & Self-Regulators & 120 & 94.93 & 3.57 & 90 & 100 \\
\hline & Total & 135 & 94.26 & 4.05 & 80 & 100 \\
\hline \multirow{3}{*}{ PUNCTUAL } & Non-self regulators & 15 & 87.67 & 5.94 & 80 & 100 \\
\hline & Self-Regulators & 120 & 95.83 & 4.01 & 80 & 100 \\
\hline & Total & 135 & 94.93 & 4.96 & 80 & 100 \\
\hline \multirow[t]{3}{*}{ ATTITUDE } & Non-self regulators & 15 & 88.47 & 4.34 & 80 & 97 \\
\hline & Self-Regulators & 120 & 98.27 & 2.04 & 90 & 100 \\
\hline & Total & 135 & 97.18 & 3.90 & 80 & 100 \\
\hline \multirow[t]{3}{*}{ GROOMING } & Non-self regulators & 15 & 93.07 & 5.59 & 85 & 100 \\
\hline & Self-Regulators & 120 & 98.28 & 2.69 & 90 & 100 \\
\hline & Total & 135 & 97.70 & 3.52 & 85 & 100 \\
\hline
\end{tabular}

A one-way between subjects ANOVA was conducted to determine if there is a significant difference among practicum students when grouped according to their cluster membership. Practicum students when grouped together according to their cluster shows a significant difference in the scope of work $\mathrm{p}<.05$ level, in terms of duties, $[\mathrm{F}(1,133)=104.16, \mathrm{p}=0]$, quality of work $[\mathrm{F}(1,133)=37.03$, $\mathrm{p}=0]$, punctuality, $[\mathrm{F}(1,133)=49.08, \mathrm{p}=0]$, attitude, $[\mathrm{F}(1$, $133)=224.95, \mathrm{p}=0]$ and grooming, $[\mathrm{F}(1,133)=37.26, \mathrm{p}=$ $0]$. Taken together, the results suggest that there were 
significant difference manifested among practicum students grouped according to their self-regulated learning in terms of duties, quality, punctuality and grooming.

Table 3.ANOVA between Self-Regulators and Non-Self Regulators in the Practicum Program

\begin{tabular}{|c|c|c|c|c|c|c|}
\hline & & Sum of Squares & $\mathrm{df}$ & Mean Square & $\mathrm{F}$ & Sig. \\
\hline \multirow[t]{3}{*}{ DUTIES } & Between Groups & 746.67 & 1 & 746.67 & 104.16 & 0 \\
\hline & Within Groups & 953.43 & 133 & 7.169 & & \\
\hline & Total & 1700.10 & 134 & & & \\
\hline \multirow[t]{3}{*}{ QUALITY } & Between Groups & 478.67 & 1 & 478.668 & 37.03 & 0 \\
\hline & Within Groups & 1719.26 & 133 & 12.927 & & \\
\hline & Total & 2197.93 & 134 & & & \\
\hline \multirow[t]{3}{*}{ PUNCTUAL } & Between Groups & 889.26 & 1 & 889.259 & 49.08 & 0 \\
\hline & Within Groups & 2410 & 133 & 18.12 & & \\
\hline & Total & 3299.26 & 134 & & & \\
\hline \multirow[t]{3}{*}{ ATTITUDE } & Between Groups & 1280.53 & 1 & 1280.533 & 224.92 & 0 \\
\hline & Within Groups & 757.20 & 133 & 5.693 & & \\
\hline & Total & 2037.73 & 134 & & & \\
\hline \multirow[t]{3}{*}{ GROOMING } & Between Groups & 362.85 & 1 & 362.848 & 37.26 & 0 \\
\hline & Within Groups & 1295.30 & 133 & 9.739 & & \\
\hline & Total & 1658.15 & 134 & & & \\
\hline
\end{tabular}

The person $r$ correlation reports the degree of freedom, which are 133. The academic performance of practicum students in the first semester has a very low correlation with the different indicators on scope of work such as with duties $r(0.262)$, quality $r(0.254)$ and attitude $r(0.204)$. Similarly, the academic performance of practicum students during their second year first semester have a very low correlation with the different indicators on scope of work such as with duties $r(0.228)$, quality $r(0.257)$, attitude $r(0.285)$ and grooming $\mathrm{r}(0.239)$ and with the second year, second semester with duties $r(0.178)$. In their academic performance in the third year second semester shows a very low correlation exist with duties $r(0.18)$ and punctuality $r(0.195)$. Lastly, it was only in the fourth year fourth semester that indicates a very low correlation with punctuality $\mathrm{r}(0.182)$ and attitude $\mathrm{r}(0.236)$.

Table 4. Pearson r Correlations Between Academic and Practicum Performance

\begin{tabular}{|c|c|c|c|c|c|}
\hline & DUTIES & QUALITY & PUNCTUAL & ATTITUDE & $0.204^{*}$ \\
\hline FIRST_1 & $0.262^{*}$ & $0.254^{*}$ & & $0.285^{*}$ & \\
\hline SECOND_1 & $0.228^{*}$ & $0.257^{*}$ & & $0.239^{*}$ \\
\hline SECOND_2 & $0.178^{*}$ & & & \\
\hline THIRD_2 & $0.18^{*}$ & & $0.195^{*}$ & & \\
\hline FOURTH_1 & & & $0.182^{*}$ & $0.236^{*}$ & \\
\hline
\end{tabular}

$* p<0.05$

\section{Discriminant Function Analysis}

The Wilk's Lambda table demonstrate that the discriminant analysis is statistically significant $(\mathrm{p}<.000)$. The classification table above shows that the overall ability of the discriminate function can predict 99.3 percent accuracy the first cluster and second cluster of practicum students (cluster $1=100$ percent; cluster $2=99.2$ percent). Among the independent variable that help predict group membership the table result reveal that the Test of Equality of Group Means which variable differ between cluster 1 and 2 on a univaraite basis. These are the second year second semester and fourth year grades, duties, quality, punctuality, attitude and grooming $(\mathrm{p}<$ 0.05). Considering the variables from a multivariate perspective the information in the Standardized Canonical Discriminant Function Coefficients table or in the Structure matrix table illustrate that attitude (0.74) and duty (0.503) were helpful in predicting group membership. Although, punctuality, quality and grooming were helpful to predict cluster membership but were not as important a predictor as 
attitude and duty. Moreover, the discriminant function correctly predicted 99.2 percent of the first cluster and 100 percent of the second cluster. The overall predictive accuracy was 99.3 percent.

\section{RESULTS AND DISCUSSIONS}

Researchers believed that self-regulation is relevant for understanding academic outcome, because through selfregulation students collect resources to achieve academic goals. A focused student can utilize cognitive strategies to solve problems and become more successful. At any academic level any student can learn to self-regulate and their academic performance improve. However, fourth year practicum students did not demonstrate a strong significant correlation between their level of academic performance and level of practicum performance (Le, Casillas, Robbins, \& Langley, 2005). Self-regulations in some studies are in terms of the non-cognitive construct such as the presence of experiential learning in the classrooms (Young, 2005). Among the practicum course the non-cognitive construct are the duties (Siadaty et al.), work quality (White \& Frederiksen, 2005), punctuality (Luna \& S $\tilde{A}_{i}$ nchez, 2005), attitude (Chen, 2009), and grooming (Bassi, Steca, Delle Fave, \& Caprara, 2007).

Self-efficacy is another non-cognitive skill identified with self-regulated learning, which students believe that their own skills can accomplish an objective (Schunk \& Zimmerman). Research validates those students who uses self-regulated strategies increases their self-efficacy, reinforcing students self-regulate further. In other words, selfefficacy enhances self-regulated learning (Pajares, 2008).

Meanwhile, self-regulated learning does not singly refer to cognitive but includes emotional, behavioral control and meta-cognitive strategies, which includes comprehension, persistence and diligence (Dinsmore, Alexander, \& Loughlin, 2008). Therefore, self-regulation involves a myriad of psychological process and set of skills. In addition self regulation develop with age, therefore, fourth year students compared to second year students involves more goal setting, planning, self monitoring and approaching for help (Schunk, 2005).

It also appears that the student attitude (motivation component) (Nicol \& Macfarlaneâ€• Dick, 2006), duties \& responsibilities (cognitive strategies) (Pajares, 2008) are the two significant indicators that separate the numerous selfregulators from the non-self-regulators in the practicum program. This specifies that proactive process that students use to acquire the necessary set of skills rather than the reactive response define SRL (Zimmerman, 2008).

The cognitive strategies identified as the duties and responsibilities of practicum students performed to get through their practicum program includes their ability in problem solving and critical thinking skills (Sungur \& Tekkaya, 2006). Critical thinking in meeting duties and responsibilities of practicum students involves a variety of skills such as using information or creating information consistent with prior knowledge learned from lower years. Practicum activities, which includes oral and written reports to convey information shows the SRL.

The motivation component, which includes selfefficacy, a belief among students that they can accomplish the practicum program enhances their attitude (Usher \& Pajares, 2008). Although students' faces challenges to overcome embedded, strong, negative self-talk they resort to selfregulated strategy, which include goal setting, monitoring and progress (Sungur \& Tekkaya, 2006). They enlist the help of their coordinator and supervisor to replace negative self-talk with positive self-instruction, which reinforces their persistence and motivation (Pintrich \& Zusho, 2007).

\section{CONCLUSION}

Although there was an increase of business students GPA as they progress academically, it was not significant. However, the significant relationship between the GPA and practicum performance is very low an indication that the meta-cognitive level does not manifest in the practicum program. On the other hand, attitude, duties and responsibilities significantly distinguish self-regulators from non-self regulators in the practicum program.

\section{RECOMMENDATIONS}

The absences of meta-cognitive component demonstrate that the practicum program should include the declarative knowledge, specifically; coordinators must identify factors that influence level of performance. Moreover, program must also include the procedural knowledge, which requires students to identify strategies and procedures. Also, include the conditional knowledge, the ability of student on why and when to use a particular strategy. One way for the program to make the three type of knowledge apparent is to have students performs demonstration through simulation. Debriefing after simulation can help coordinators identify the student's level of declarative, procedural and conditional knowledge.

\section{CITED LITERATURES}

[1] Alexander, P. A. (2008). Why this and why now? Introduction to the special issue on metacognition, self-regulation, and selfregulated learning. Educational Psychology Review, 20(4), 369372 .

[2] Azevedo, R. (2005). Using hypermedia as a metacognitive tool for enhancing student learning? The role of self-regulated learning. Educational psychologist, 40(4), 199-209.

[3] Azevedo, R. (2009). Theoretical, conceptual, methodological, and instructional issues in research on metacognition and selfregulated learning: A discussion. Metacognition and Learning, 4(1), 87-95.

[4] Azevedo, R., \& Hadwin, A. F. (2005). Scaffolding self-regulated learning and metacognitionâ€"Implications for the design of computer-based scaffolds. Instructional Science, 33(5), 367-379.

[5] Banyard, P., Underwood, J., \& Twiner, A. (2006). Do Enhanced Communication Technologies Inhibit or Facilitate Selfâ€• regulated Learning? European Journal of Education, 41(3â€• 4), 473-489.

[6] Barnard-Brak, L., Paton, V. O., \& Lan, W. Y. Profiles in selfregulated learning in the online learning environment. The 
International Review of Research in Open and Distance Learning, 11(1), 61-80.

[7] Bassi, M., Steca, P., Delle Fave, A., \& Caprara, G. V. (2007). Academic self-efficacy beliefs and quality of experience in learning. Journal of Youth and Adolescence, 36(3), 301-312.

[8] Chen, C.-M. (2009). Personalized E-learning system with selfregulated learning assisted mechanisms for promoting learning performance. Expert Systems with Applications, 36(5), 8816-8829.

[9] Clinebell, S. K., \& Clinebell, J. M. (2008). The tension in business education between academic rigor and real-world relevance: The role of executive professors. Academy of Management Learning \& Education, 7(1), 99-107.

[10] Dinsmore, D. L., Alexander, P. A., \& Loughlin, S. M. (2008). Focusing the conceptual lens on metacognition, self-regulation, and self-regulated learning. Educational Psychology Review, 20(4), 391-409.

[11] Kaplan, A., Lichtinger, E., \& Margulis, M. The situated dynamics of purposes of engagement and self-regulation strategies: A mixed-methods case study of writing. Teachers College Record, 113(6).

[12] Kuiper, R., Murdock, N., \& Grant, N. Thinking strategies of baccalaureate nursing students prompted by self-regulated learning strategies. The Journal of nursing education, 49(8), 429-436.

[13] Le, H., Casillas, A., Robbins, S. B., \& Langley, R. (2005). Motivational and skills, social, and self-management predictors of college outcomes: Constructing the Student Readiness Inventory. Educational and Psychological Measurement, 65(3), 482-508.

[14] Lennon, J. M. Self-regulated learning. Noncognitive Skills in the Classroom: New Perspectives on Educational Research, 69.

[15] Loyens, S. M. M., Magda, J., \& Rikers, R. M. J. P. (2008). Selfdirected learning in problem-based learning and its relationships with self-regulated learning. Educational Psychology Review, 20(4), 411-427.

[16] Luna, M., \& SÃ $i n c h e z$, D. (2005). Profiles of autonomy in the field of foreign languages. Profile, 6, 133-140.

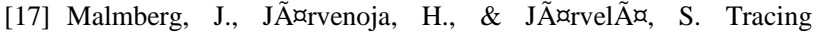
elementary school studentsâ€ $€^{\mathrm{TM}}$ study tactic use in gStudy by examining a strategic and self-regulated learning. Computers in Human Behavior, 26(5), 1034-1042.

[18] Matthews, J. S., Ponitz, C. C., \& Morrison, F. J. (2009). Early gender differences in self-regulation and academic achievement. Journal of Educational Psychology, 101(3), 689.

[19] McLoughlin, C., \& Lee, M. J. W. Personalised and self regulated learning in the Web 2.0 era: International exemplars of innovative pedagogy using social software. Australasian Journal of Educational Technology, 26(1), 28-43.

[20] Moos, D. C., \& Azevedo, R. (2008). Monitoring, planning, and self-efficacy during learning with hypermedia: The impact of conceptual scaffolds. Computers in Human Behavior, 24(4), 16861706.

[21] Nicol, D. J., \& Macfarlaneâ€• Dick, D. (2006). Formative assessment and selfâ $\bullet$ regulated learning: a model and seven principles of good feedback practice. Studies in higher education, 31(2), 199-218.

[22] Pajares, F. (2008). Motivational role of self-efficacy beliefs in self-regulated learning. Motivation and self-regulated learning: Theory, research, and applications, 111-139.
[23] Perry, N. E., Hutchinson, L., \& Thauberger, C. (2007). Mentoring student teachers to design and implement literacy tasks that support self-regulated reading and writing. Reading \& Writing Quarterly, 23(1), 27-50.

[24] Perry, N. E., Hutchinson, L., \& Thauberger, C. (2008). Talking about teaching self-regulated learning: Scaffolding student teachersâ€ $€^{\mathrm{TM}}$ development and use of practices that promote selfregulated learning. International Journal of Educational Research, 47(2), 97-108.

[25] Pintrich, P. R., \& Zusho, A. (2007). Student motivation and selfregulated learning in the college classroom. In The scholarship of teaching and learning in higher education: An evidence-based perspective (pp. 731-810): Springer.

[26] Schunk, D. H. (2005). Self-regulated learning: The educational legacy of Paul R. Pintrich. Educational psychologist, 40(2), 85-94.

[27] Schunk, D. H., \& Zimmerman, B. J. Motivation and self-regulated learning: Theory, research, and applications: Routledge.

[28] Siadaty, M., Jovanovic, J., Pata, K., Holocher-Ertl, T., Gasevic, D., \& Milikic, N. A semantic web-enabled tool for self-regulated learning in the workplace. Paper presented at the Advanced Learning Technologies (ICALT), 2011 11th IEEE International Conference on.

[29] Sungur, S., \& Tekkaya, C. (2006). Effects of problem-based learning and traditional instruction on self-regulated learning. The journal of educational research, 99(5), 307-320.

[30] Usher, E. L., \& Pajares, F. (2008). Self-Efficacy for SelfRegulated Learning A Validation Study. Educational and Psychological Measurement, 68(3), 443-463.

[31] Vollmeyer, R., \& Rheinberg, F. (2006). Motivational effects on self-regulated learning with different tasks. Educational Psychology Review, 18(3), 239-253.

[32] White, B., \& Frederiksen, J. (2005). A theoretical framework and approach for fostering metacognitive development. Educational psychologist, 40(4), 211-223.

[33] Winne, P. H. Improving measurements of self-regulated learning. Educational psychologist, 45(4), 267-276.

[34] Young, M. R. (2005). The motivational effects of the classroom environment in facilitating self-regulated learning. Journal of Marketing Education, 27(1), 25-40.

[35] Zimmerman, B. J. (1989). Models of self-regulated learning and academic achievement. In Self-regulated learning and academic achievement (pp. 1-25): Springer.

[36] Zimmerman, B. J. (1990). Self-regulated learning and academic achievement: An overview. Educational psychologist, 25(1), 3-17.

[37] Zimmerman, B. J. (2008). Investigating self-regulation and motivation: Historical background, methodological developments, and future prospects. American Educational Research Journal, 45(1), 166-183.

[38] Zimmerman, B. J., \& Kitsantas, A. (2005). The Hidden Dimension of Personal Competence: Self-Regulated Learning and Practice.

[39] Zimmerman, B. J., \& Schunk, D. H. (1989). Self-regulated learning and academic achievement: Theory, research, and practice: Springer-Verlag Publishing. 